Marc L. Greenberg

University of Kansas

\title{
Prekmurje Grammar as a Source of Slavic Comparative Material
}

Prispevek, predstavljen kot referat na 16. bienalnem simpoziju o južnoslovanskih jezikih, zagovarja objavo Pavlove rokopisne prekmurske slovnice Vend nyelvtan, dokončane 1. 1942. Čeprav je prvotni namen slovnice, tj. uveljavitev pokrajinskega knjižnega jezika, zastarel, rokopis ponuja informacije o posebnem ustroju prekmurščine in je s tem tudi dragocen vir za tipološke, primerjalne in zgodovinske študije slovanskih jezikov.

The paper, which was prepared for and delivered at the 16th Biennial Balkan and South Slavic Conference in Banff, Canada, makes the case for the publication of the 1942 Prekmurje Slovene grammar in manuscript, Avgust Pavel's Vend nyelvtan, not for the purpose of reviving a competing literary language, but as a useful source of information for typological, comparative and historical studies of the Slavic languages.

Slavic linguistics as it enters the twenty-first century can be seen as a mature field, given that its beginnings in the period of historical-comparative studies dates to the beginning of the nineteenth century with Dobrovskýs taxonomy of Slavic "dialects." At least as far as the historical and comparative end of the spectrum of inquiry, new research cannot hope to yield profoundly new discoveries, but it can yield more sophisticated and fine-grained analyses. Moreover, it still has room to remove blind spots in its vision. One of the fundamental operating procedures in Slavic linguistics - so fundamental, in fact, that it is virtually never discussed - is the use of standard languages of contemporary nation states as the primary unit of analysis. This is a practical starting point, as one needs a finite and manageable set of data to analyze. Dialect material is the domain of the dialectological connoisseur in view of the fact that the amount of variation to be considered is in principle endless and, moreover, it is generally impractical to pore over hundreds of obscure publications to ferret out village-level variation. Ignoring dialect differentiation, however, can render a study partially or largely meaningless, particularly when modern standard languages are mapped directly to putatively equivalent proto-dialects (see, for example, the critique in Greenberg 2004). The consideration of alternative and even defunct norms, such as the reconstructed Novgorodian dialect, based on a growing body of attestations from the Birchbark Letters, yields new insights into the development of early Slavic (see, for example, Vermeer 1986). Slavists who comparatively examine data from standard-language grammars might consider also the grammars of languages that were elaborated for standardization on the basis of a particular dialect, but for historical reasons never made it to the status of official standard language.

${ }^{1}$ This paper was prepared for and delivered at the Sixteenth Biennial Balkan and South Slavic Conference in Banff, Alberta, Canada on 3 May 2008. 
This paper proposes that the grammar of the Prekmurje dialect of Slovene is one such grammar that has the potential to yield new insights in historical-comparative studies of Slavic languages. The Prekmurje dialect is at the Slavic level a close relative of, yet strikingly distinct from the Slovene standard language, which is based on the central dialects of Carniola; moreover, the Prekmurje dialect has a centuries-long tradition of writing, giving it not only a synchronic point of comparison, but some diachronic depth with older texts surviving.

In the context of Slovene dialects the Prekmurje dialect is perceived to be the "ugliest" and the least prestigious by Slovene speakers (Lundberg 2007: 104-105). Evidently this view arises from the fact that standard Slovene is based primarily on features selected from the central, Carniolan dialects, and that Prekmurje is the most distant from the center both in geographical and structural terms. The feeling is mutual: Prekmurje speakers are largely in agreement in regarding the dialect of Ljubljana, the most central of Carniolan dialects, as the least attractive from their perspective (loc. cit.). While these synchronic sociolinguistic data, coupled with the decisions made in the nineteenth century to unify the Slovene nation around a standard language built primarily on Carniolan structural features, are both effect and cause of the abandonment of a Prekmurje standard, such considerations only highlight the utility of a peripheral dialect for historical comparative purposes; indeed, "high-prestige data can come from once low-prestige sources" (Janda and Joseph 2003: 16-17). Naturally, outside of the Slovene context the prestige issue ceases to exist.

\section{Avgust Pavel's Vend nyelvtan and its place in the Prekmurje writing tradition}

The Prekmurje Slovene dialect has been used for liturgical and literary purposes since at least the late sixteenth century (the lost Agenda vandalica of 1587) with the first major extant publication being Franc Temlin's Mali katechizmus (1715). Literacy in the region probably dates to the late $16^{\text {th }}$ century with the introduction of a Protestant school under István Bánffy of Upper Lendava (Jesenšek 1998: 121). A signal achievement is Protestant pastor Števan Küzmič's 1771 publication of Nouvi zákon, which is described as testamentom goszpodna nasega Jezusa Krisztusa zdaj oprvics z grcskoga na sztári szlovenszki jezik obrnyeni.

The first attempt to standardize the language in a modern sense and create (what is, in effect, a descriptive) grammar of it took place under highly charged political circumstances during the Second World War (Priestly 1996) at a time when the Slovene national language project had been nearly completed. Because the Hungarian ethnolinguistic engineering project failed during the War, the grammar-Avgust Pavel's (1886-1946) Prekmurje Grammar (Vend nyelvtan), completed in 1942 - remained unpublished. Nevertheless, the Vend nyelvtan (hereafter VN) continues to be a unique and important resource on the grammatical structure of the Prekmurje dialect and, consequently, of comparative material for Slavic studies (Greenberg 1989). For this reason, the present author is working as part of a team of three scholars to create an annotated critical edition and translation of the grammar (written in Hungarian), which is projected for publication for the first time in 2009- some 67 years after the manuscript was completed. 


\section{How to read the Vend nyelvtan}

Pável's Vend nyelvtan continues the practice of rendering the sound system by means of the orthographic conventions of Hungarian. In contrast to the Western South Slavic gajica traditions in which Latin consonant letters are modified with diacritic marks to accommodate the richer fricative and affricate system of Slavic languages, the Hungarian system of di- and trigraphs is employed. Thus Fig. 1 reproduces Pável's consonant chart on p. 11 of VN. Of note is the use of the single grapheme $s$ for [̌̌], following Hungarian orthographic norms, e.g., düsa 'soul', grêsnik 'sinner'. The corresponding dental fricative is rendered with the digraph $s z$, e.g., jeszti 'to eat', zimszki 'winter (adj.)'. The voiced relations are thus asymmetrical as the digraph $z s$ represents [ž] and $z$ by itself is [z]: hizsa 'house', zsena 'wife', mozoj 'pimple', zôb 'tooth'. Since the affricate [č] exists in Hungarian, the corresponding digraph cs is used for the sound in VN: cslovek 'person', szvêcsa 'candle' and the $c$ for [ts], deca 'children'.

Figure 1: VN consonants $(\$ 38)$

\begin{tabular}{|l|l|l|l|l|l|l|l|l|l|l|l|l|l|l|}
\hline voiced & $b$ & $d z s$ & $d$ & $g$ & $g j$ & $v$ & $z$ & $z s$ & $j$ & $l$ & $m$ & $n$ & $n j$ & $r$ \\
\hline voiceless & $p$ & $c s$ & $t$ & $k$ & $t j$ & $f$ & $s z$ & $s$ & & & & & & \\
\hline
\end{tabular}

Figure 2: VN vowels $(\$ 10)$

\begin{tabular}{|l|l|l|l|l|l|l|l|}
\hline short & $a$ & $e$ & $i$ & $o$ & $\ddot{o}$ & $u$ & $\ddot{u}$ \\
\hline long & $\dot{a}$ & $\dot{e}$ & $\dot{l}$ & $\dot{o}$ & $\ddot{o}$ & $\dot{u}$ & $\ddot{u}$ \\
\hline
\end{tabular}

As illustrated in Fig. 2, vowels are distinguished orthographically between short and long. Aside from length, diacritics also mark the contrast between back and front rounded vowels, thus, as in Hungarian, $o-\ddot{o}$ and $u-\ddot{u}$, e.g., vöra 'hour', dvora 'court (gen. sg.)'; csun 'shuttle on a loom', csüda 'miracle'.

With regard to quantity diacritics, these work in a general sense as in Hungarian, as well, where the acute (or double acute in the case of front rounded vowels) marks a long vowel. In contrast to Hungarian, however, ictus is not fixed on the first syllable of the word, but, rather, is assigned to a particular syllable in the word, which may be long or short. Long vowels occur only concomitantly with stress. For example, length is marked in the root vowel of the nominative singular of szád 'fruit', but in the genitive singular the root vowel becomes unstressed and thus by default short — sad" 'fruit (gen. sg.)'. Note that the length in the desinence is marked by replacing the dieresis with the double acute, as in Hungarian. Straight length alternations are marked with the absence or presence of the acute mark, e.g., keden 'week'—v kédni 'during the week'. Note that the place of stress is potentially ambiguous, since there is no provision for marking place of stress in words in which the stress is short. This is not true in disyllables, as short stress in the final syllable of polysyllabic words does not occur, so forms such as vöra, dvora, csüda, and keden are all predictably stressed on the first syllable. 
The most notable discrepancy with regard to Hungarian orthography is in marking the Prekmurje diphthongs /ou/ and /ei/, which come from long PSl $* o$ and $* \check{e}$, respectively. These are marked with the carat above the corresponding monophthongal letters, e.g., vola 'mood, volition'-po vôli 'in the mood for, by one's volition'; goszpé 'lady (gen. sg.)'—goszpê 'lady (dat./loc. sg., nom./acc. du.)'.

A less-then-optimal by-product of Hungarian orthography is the loss of specification between short closed /e/ and short open / $/$ /. Thus cslovek, csloveka has closed /e/ in the second syllable. Thus zsena 'wife', zsenitev 'marriage' have open $/ \varepsilon /$ in the first syllable and, in the second word, the third syllable, as well. Of course, native speakers have no trouble making the distinction in speech.

\section{Complementizers in Prekmurje Slovene}

To illustrate the notion of the utility of considering Prekmurje as a source of both typological and historical data for South Slavic, let us examine the status of the complementizer $d a$, which is uncontroversially considered to be the general marker of subordinate clauses in both Slovene and BCS. ${ }^{2}$ For example, we find in Ammann and van der Auwera (2004: 300) a study of South-East European languages in which two types emerge, whereby languages in group A distinguish complementizers for realis/irrealis and languages in group B make no such distinction. Group A includes Modern Greek (óti/na), Albanian (që/të), Macedonian (deka oti/da), Bulgarian (če deto/da), Balkan Romani $(\mathrm{kaj} / \mathrm{te})$, Romanian (că/să), Southern Italian dialects

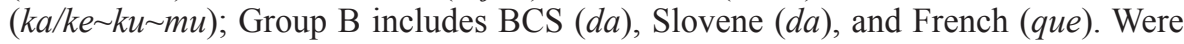
the authors to have taken into consideration Prekmurje data in the Vend nyelvtan, the picture would be considerably less tidy. Just as in Standard Slovene, $d a$ in the variety of Prekmurje Slovene presented in $\mathrm{VN}^{3}$ introduces subordinate clauses:

Priso szam k tebi, da bi ti pomágo.

$(\mathrm{VN} \S 423)$ came-M-SG AUX-1-SG to you-DAT-SG COMP COND you-DAT-SG help-MASC-SG 'I came to you so that I can help you.'

(2) Prišel sem k tebi, da bi ti pomagal.

(Standard Slovene)

However, VN allows two possibilities for the choice of COMP, $d a \sim k a$, in cases such as (3) and (5), the less preferred variant (following Pavel's indications) appearing in parentheses, whereas Standard Slovene (4), (6) permits only $d a$ :

$$
\text { Zavêszt, da ( ka) szkoro ozdraví, ga je neszkoncsno razveszelíla. }
$$

\footnotetext{
${ }^{2}$ I use the label BCS as a cover term, now widely accepted in American Slavistics, to refer collectively to the Štokavian-based standard languages Bosnian, Croatian, and Serbian.

${ }^{3}$ It should be noted that $d a$ is the marked member of the opposition between $d a / k a$, the subordinating conjunction $\mathrm{ka}$ being not only more frequent as a marker of subordinate clauses, but virtually the only one found the Prekmurje spoken language of today. More will be said about this below.
} 
awareness-N-SG-F COMP soon recover-3SG-PF him-ACC AUX-3SG to-no-end-ADV pleased-F-SG

'The notion that he would soon recover pleased him to no end.'

Zavest, da bo kmalu ozdravel, ga je neskončno razveselila.

(Standard Slovene)

'The notion that he would soon recover pleased him to no end.'

Pravo mi je, ka ( da) mi zavszema zavüpa.

$(\mathrm{VN} \S 436)$

Said-M-SG me-DAT AUX-3SG COMP me-DAT fully-ADV trust-3SG-IMPF

'He told me that he completely trusts me.'

Rekel mi je, da mi popolnoma zaupa.

(Standard Slovene).

'He told me that he completely trusts me.'

Pavel points out that in cases such as (1) the variants $k a$ or $k a b i$ would be incorrect, as intentionality cannot be signaled with $k a$, only with $d a(\S 445)^{4}$ and that $d a$ is used more restricted instances where the proposition is potential ("teljesülhetö") rather than asserted ("valódi"), which we will refer to in the continuation with the labels irrealis and realis, respectively. The option of using one or the other complementizer is possible in cases such as (3) and (4) where, according to Pavel, the main clause contains a verb expressing an emotion, though $d a$ is in this case preferred: Trno me veszeli', da ( $\boldsymbol{k} \boldsymbol{a})$ szi zse pá zdrav 'I am very pleased that you are healthy once again' (§444). In (5), however, $k a$ is preferred over $d a$ in assertions, i.e., where the main clause does not contain a modal verb. It follows therefore that in contrast to Standard Slovene, which lacks this option, not only does the VN standard language possess more than one complementizer, but that $d a$ is marked for irrealis, as in the South-Eastern European languages adduced by Ammann and van der Auwera.

Pavel's rules are at odds with the Prekmurje spoken dialect of today, where the modal $d a$ is rarely, if ever, encountered in everyday speech. ${ }^{5}$ It might be surmised that the form was borrowed from Standard Slovene for the purpose of standardization and never entered the spoken language. If this is the case, then the borrowing entered the written tradition long before VN. For example, it is found in Franc Temlin's Mali Katechismus of 1715 (Temlin [1986]: 13): Szpomenifze cslovecse, da den fzobotni prefzvetis 'Remember, man, that you must sanctify the Sabbath day'; and Števan Küzmič's Vöre krsztsánszke krátki návuk of 1754: pomágajmo, da fze vfza nyegova obdr'zijo 'let us help so that all his (...) may be sustained' (quoted in Novak 2007: s.v.). It might be surmised that $d a$ could have been re-borrowed by Pavel from central Slovene dialects through the intermediary of the contemporary Slovene standard

${ }^{4}$ The point is evidently normative. Compare example (8).

${ }^{5} \mathrm{I}$ base the observation on my own field notes and am grateful for confirmation of this point by a native speaker from the area, Mojca Horvat (ZRC SAZU), as well as an anonymous reviewer and his/her named informant Tadeja Hercog, born 1980, from Cankova, Pavel's native village. Logically, the lack of the distinction today cannot demonstrate its earlier non-existence. 
language, with which Pavel was thoroughly familiar. If this is the case, it would mean that Pavel invented a model for the distribution of $d a$ vs. $k a$, a distinction that is not available in either the central dialects or the Slovene standard language. While this is possible, it does go against Pavel's prevailing practice of basing his normative grammar on actual spoken usage of his day while removing narrowly local variation.

Once we look at speech collected around the end of the nineteenth and the beginning of the twentieth century, however, we in fact find the variation in speech that is reflected in VN. Thus in Pavel's Cankova tales $(1917,1918)$, we discover on the very first page an example in which $d a$ may occur according to $\mathrm{VN}$ after a verb of potential (irrealis) proposition:

ädänòvomi sta si sä̀ zalübila, ka ädän òvoga nìgdár nä poviřăäta. ${ }^{6}$

one-another-DAT-SG-M AUX-2sG self-DAT promise-PAST-DU COMP REFL one another-ACC-SG never not spurn-3DU-PF

'They promised each other that they would never spurn one another.'

Conceivably, here $k a$ might be contrasted with temporal $d a$ (see below), which occurs in the next sentence of the narrative: Da jä poibár ädändvàisäti lèi star gráto, mògo jä iti na štệlingo (166-167) 'When the boy became twenty-one years old, he had to go for his military service.' A similar effect of triggering the less expected possibility may be seen in example (8), where the dependent clause can be seen as a factual instantiation framed by a (negative) hypothetical proposition. Alternatively, the hypothetical antecedent may trigger a temporal reading, just as it does in English, which admits either when or that:

Kà bi näbi bùuu žàlostän - právi srmák - da san tòu dèitäcä òudo!

How NEG-COND was-M-SG sad-M-SG say-3SG-IMPF wretch-NOM-SG COMP AUX1SG this-ACC-SG-N baby-ACC-SG-N sold-M-SG

"'How would I not be sad," said the wretch, "when/that I have sold this baby!"”

Prekmurje grammar and Slovene/BCS contrast in that Prekmurje Slovene uses the complementizer $d a$ with the meaning 'when', as illustrated in (9), which normally is rendered in Standard Slovene with ko (10).

Te prídi, da mo te zváli. then/at-that-time come-IMP-2sG COMP fut-AUX-1PL you-ACC call-M-PL 'Come when we call you.'

${ }^{6}$ The stress markings from Pavel's transcription are to be read as follows: the grave sign over a vowel designates a short-stressed vowel, the acute sign a long-stressed vowel. For typographical reasons (and because they are irrelevant to the present discussion) some details of the transcription are left out, such as the reduction of unstressed $i$, marked by a dot placed under the letter. 
Pridi takrat, ko te bomo poklicali.

(Standard Slovene) come-IMP-2sG then/at-that-time COMP you-ACC fut-AUX-1PL call-1PL 'Come when we call you.'

The temporal $d a$ is etymologically distinct from the modal $d a$ in (1), (3), and (5). The modal $d a$ comes from a lative particle originating in a demonstrative pronoun $\left(<\mathrm{IE} * d o h_{2}\right)$ (Kopečný et al 1980: 148-149; Snoj 2003: 94); the temporal $d a$ is connected with the particle from which temporal adverbs have been built, e.g., OCS $s b d a$ 'now', BCS sada 'now' (Kopečný et al 1980: 149-151, 623-624; Snoj 2003: 643), presumably $<$ IE $d^{h} o H$, cf. OHG $d \bar{o}$, OE $\bar{p} \bar{a}$ 'then'. The interrogative temporal adverb in Prekmurje is similarly constructed: $g d a$ 'when' (VN $\$ 316)<* k b-d a$. It is conceivable, though not demonstrable, that the temporal complementizer $d a$ in Prekmurje is in fact a reduction of an earlier * $g d a$.

To get a sense of the distribution of the use of $d a$ and $k a$ in its three functions, temporal ('when'), irrealis, and realis, a small collection of transcribed tales published by Pavel $(1917,1918)$ were scanned, yielding 118 total instantiations of subordinate clauses introduced by one or the other of the two complementizers (others, such as the optative naj and temporal ar 'up until' were ignored - these accounted for just a few tokens). The results are summarized in Figure 3. It may be the case that this distribution represents a usage that was in place at the beginning of the twentieth century, but that has now become obsolete, though the point remains to be verified. As mentioned above, the distribution appears to have shifted a century later to temporal $d a$, with $k a$ introducing non-temporal subordinate clauses. The results adduced here would thus demonstrate a tendency towards these absolute targets, where $84.9 \%$ of the temporal readings are rendered with $d a$, and $96.6 \%$ of the realis readings are rendered with $\mathrm{ka}$. Irrealis readings are almost evenly split, with $d a$ used for $44.4 \%$ and $k a$ for $55.5 \%$. As can be seen in Figure 3, the functions of each are distributed in inverse proportion, with the likelihood of $d a$ being temporal $>$ irrealis $>$ realis and $k a$ being realis $>$ irrealis $>$ temporal. Of the two, $d a$ is marked, occurring in roughly a third of all instances and $k a$ occuring in the remaining two thirds.

Figure 3. Distribution of $d a, k a$ in Pavel 1917, $1918(\mathbf{n}=118)$

\begin{tabular}{|c|c|c|c|c|c|c|c|c|}
\hline & \multicolumn{4}{|c|}{$d a$} & \multicolumn{4}{|c|}{$k a$} \\
\hline & $\begin{array}{l}\text { number } \\
\text { of } d a \\
\text { tokens }\end{array}$ & $\begin{array}{l}\text { as } \% \text { of } \\
d a\end{array}$ & $\begin{array}{l}\text { as \% } \\
\text { of } d a \\
+k a\end{array}$ & $\begin{array}{l}\text { as } \% \text { of } \\
\text { function }\end{array}$ & $\begin{array}{l}\text { number } \\
\text { of } k a \\
\text { tokens }\end{array}$ & $\begin{array}{l}\text { as } \% \text { of } \\
k a\end{array}$ & $\begin{array}{l}\text { as } \% \text { of } \\
k a+d a\end{array}$ & $\begin{array}{l}\text { as } \% \text { of } \\
\text { function }\end{array}$ \\
\hline temporal & 28 & $66.6 \%$ & $23.7 \%$ & $84.9 \%$ & 5 & $6.6 \%$ & $4.2 \%$ & $15.1 \%$ \\
\hline irrealis & 12 & $28.6 \%$ & $10.2 \%$ & $44.4 \%$ & 15 & $19.7 \%$ & $12.7 \%$ & $55.5 \%$ \\
\hline realis & 2 & $4.8 \%$ & $1.7 \%$ & $3.4 \%$ & 56 & $73.7 \%$ & $47.5 \%$ & $96.6 \%$ \\
\hline Total & 42 & $100.0 \%$ & $35.6 \%$ & & 76 & $100.0 \%$ & $64.4 \%$ & \\
\hline
\end{tabular}

This situation should not surprise us, as it is clear from the wider Slavic context that the particle $d a$ started out its life as a marker of optative propositions, e.g., OCS vbdite $i$ molite se da ne vbnidete vo napastb 'Watch and pray that you may not enter into temptation', and it is generally assumed that in BCS and Slovene it spread 
from potential to assertive (indicative) propositions as its modal semantics weakened (Grickat 1975: 73-78). It is thought that the spread progressed from west to east, a process that Grickat terms a "Balkanism in regression" (ibid.: 74), presumably on the basis of the attestations of this usage in the early eleventh-century Freising Folia, e.g., Tose uиeruiu u Bog uzemogoki, i u iega Zin, i u Zuueti Duh, da ta tri imena $<$ sunt $>$ edin Bog ... 'I also believe in God almighty and his Son and in the Holy Ghost that these three names are one God ...' ( $F F$ III).

On the other hand, the complementizer $k a$ originates in a lative or instrumental pronominal form IE $* k^{w} e h_{2}$, cognate with Latin $q u \bar{a}$ 'in what manner' (Snoj 1996: 190-191; Sihler 1995: 268). ${ }^{7}$ Indeed, the sense 'in what manner' is included in the semantic range of Prekmurje pronominal kä, as can be seen in example (8), below. The form is attested with various semantic developments in Po. dial. ka ta idziesz 'where are you going', Bg. ka smo to čuli, taka go kazvame 'as we heard it, so we tell it' (Kopečný 1980: 325). It is moreover presumed to be the basis for the formation of the Slovene and Kajkavian pronoun $k a j$ 'what' $<* k a-j b$ (Snoj 1996). The relic form $k o$, glossed as 'what', is also found in Carinthian Slovene fossilized phrases Ko pa iẽ? Ko pa b_õ? Ko pa sa rèkli? 'What is it?/What's the matter?', 'What will happen?', 'So what did they say?' (Zdovc 1972: 109), ${ }^{8}$ which have direct correlates in Prekmurje, cf. kå gé 'What is it?/What's the matter?' (Mukič 2005: 143), though in contrast to Carinthian, in Prekmurje Slovene (stressed) pronominal $\mathrm{ka}$ is the normal form for 'what'.

Prekmurje Slovene with respect to complex constructions belongs to a type that is divergent from Slovene and BCS, but also includes complexities that have been attributed to the Balkan Sprachbund. The claim here is of course not that Prekmurje belongs to the Balkan Sprachbund, but that it both reflects an earlier stage of the spread of $d a$ from irrealis to realis that otherwise is reflected in Slovene and BCS as well as had its own particular development of a contrast between temporal $d a$ and realis $k a$. It is thus a divergent type that is worth including in the typology of Slavic subordination. In historical perspective, Prekmurje Slovene again shows us a useful peripheral case that indicates complexities that have disappeared in the more innovative center.

\section{Phonological developments}

In previous papers I have elaborated on phonological and morphonological issues that illustrate the special and archaic features of the Prekmurje dialect. Here I would like to focus on just two illustrations in the vocalic system that illustrate the notion that Prekmurje belongs to a related but divergent set of developments from those that occurred at the center of the Slovene speech territory.

${ }^{7}$ As Sihler points out, it is impossible to determine whether Lat. quā (and, consequently, Slavic * $k$ á) continue the IE instrumental or ablative, as both have the same reflex in the desinence (loc. cit.).

${ }^{8}$ This interpretation differs from Zdovc's (loc. cit.), who assumes that the form is derived from an earlier $* k \dot{o}$, though points out that this instance of final stressed $-\dot{o}$ is unique (31). The development becomes understandable if one assumes that the form derives from * $k$ ä and that labialized $* a$ was inherited rather than innovative (Greenberg 2000: 113); see also discussion below in the section on phonological developments. 
Prekmurje is part of an areal that indicates a persistent division of phonological isoglosses that cut across the Slovene and northern Croatian (Kajkavian) territory at the Sava river (Greenberg 2000, 2006), which I label Sava-N (north of the Sava) and Sava-S (south of the Sava). An example of the systemic persistence of a Sava-N vs. Sava-S division lies in the reflexes of vocalized jers, which in turn goes back to the distinction between a system in which the contrast between low vowels were marked by round vs. non-round (Sava-N) and front vs. back (Sava-S), where Sava-S represents the innovative system (Greenberg 2000: sections 19, 24). In Sava-N, which preserved Proto-Slavic $* a$ with labialization at the time of the vocalization of strong jers, the reflexes of vocalized long jers systematically merge with low front vowels, the identity of which depended on which low front vowels were available at the moment at which this happened. For example, in Carinthian and Pannonian the merger occurred at a moment when $* \check{e}$, having diphthongized, raised, such that lengthened strong jers could have merged only with *e (and later $* e)$; in Kajkavian (Sava-N) the merger occurred with $* \check{e}$ at a time before its diphthongization and raising. Wherever labialization of $* a$ was not preserved, strong jers under conditions of length merged with $* a$. The developments, illustrated in Figures $4-9$, must be viewed as a series of overlapping innovations unfolding at different rates of rapidity. For example, diphthongization and raising of $* \check{e}$ occurs later in Sava-N Kajkavian, represented in Figure 8, is not a discrete development but a later arrival of the same innovation as in Figure 6 (Sava-N) with different results owing to the systemic realignment of phonetic values as illustrated in Figure 7. ${ }^{9}$ Figures 6 and 7 assume the archaic square pattern of four vowels before the rephonologization of quantity to quality: $\overline{\mathrm{I}} / \overline{\mathrm{I}}-\overline{\mathrm{U}} /$ $\widetilde{U}-\bar{E} / \breve{E}-\bar{A} / \breve{A}$. In Figure 5 the square bracketed vowels indicate explicit phonetic values where this becomes relevant for the changes discussed, so * $\overline{\mathrm{E}}=[\ddot{a}]$ (jat), Sava$\mathrm{N} * \overline{\mathrm{A}}=[\AA ̊ a]$, Sava-S $* \overline{\mathrm{A}}>$ [a]. Figure 6 represents a later stage, after the merger of $* \breve{I}$ and $\breve{\mathrm{U}}$, here represented as [ə] (though it may have at this stage been a tense [e]). At the same time $* \overline{\mathrm{E}}$ shifts to [eä] as part of the quantity $>$ quality rephonologization process, avoiding merger with * $\overrightarrow{\mathrm{E}}[\ddot{\mathrm{a}}]$. However, as Figure 7 illustrates, the diphthongization process does not occur instantaneously, but rather, spreads $\mathrm{W}>\mathrm{E}$, during which time in Proto-Kajkavian the reflexes of $* \overline{\mathrm{E}}, * \breve{\mathrm{I}}, * \mathrm{U}$ had hitherto merged as [ä]. Once diphthongization reached Proto-Kajkavian, the innovation affected both jat and jers (Figure 8). In this respect, Pannonian Slovene and Kajkavian end up having a superficially similar contrast, including in phonetic detail, of $\ddot{a}-a ̊$ in its low-vowel series, albeit with a divergent distribution of the historical entities. The outcomes are illustrated in Figure 9.

Figure 4. Proto-Slavic input

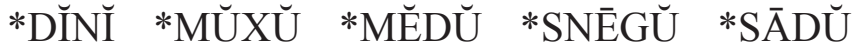

\section{Figure 5. Delabialization of *a (Sava-S)}

\begin{tabular}{|c|c|c|c|c|c|}
\hline Sava-N & $* d b n b$ & ${ }^{*} m b x b$ & $*_{m e d z}$ & $*_{s n}[\ddot{a}] g b$ & $*_{s}[\mathrm{a}] d z$ \\
\hline Sava-S & $* d b n b$ & $*_{m b x b}$ & $*_{m e d z}$ & $*_{s n}[\ddot{a}] g b$ & $*_{s}[\mathrm{a}] d z$ \\
\hline
\end{tabular}

${ }^{9}$ The Kajkavian part of this explanation owes to a modification of an insight by Vermeer in his seminal 1983 paper. 
Figure 6. Diphthongization and raising of jat I

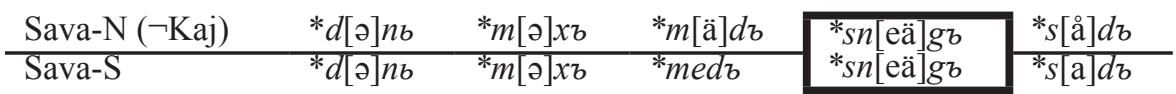

Figure 7. Merger of lengthened strong jers

\begin{tabular}{|c|c|c|c|c|c|}
\hline Sava-N ( $\neg$ Kaj) & $* d[a ̈]] n b$ & $*_{m}[a ̈] x b$ & $*_{m} m[\ddot{a}] d b$ & $*_{s n[\mathrm{e} a ̈] g z}$ & $*_{s}[\mathrm{a}] d \mathrm{~b}$ \\
\hline Sava-N Kaj & $* d[a ̈] n b$ & $*_{m}[\ddot{a}] x b$ & $*_{m}[\mathrm{e}] d b$ & $*_{s n}[\ddot{a}] g b$ & $*_{s}[\mathrm{a}] d \mathrm{~b}$ \\
\hline Sava-S & $* d[a] n b$ & ${ }^{*} m[\mathrm{a}] x \mathrm{~b}$ & *medb & $*_{s n[\text { eä }] g z}$ & $*_{s}[\mathrm{a}] d \mathrm{~b}$ \\
\hline
\end{tabular}

Figure 8. Diphthongization and raising of jat II (Sava-N Kaj)

Sava-N Kaj $\quad * d$ [eä]nb $\quad *_{m}[$ eä $] x b \quad *_{m}[\mathrm{e}] d b \quad *_{s n[\text { eä }] g z} \quad *_{s}[\mathrm{a}] d b$

Figure 9. Modern (regularized) outcomes

\begin{tabular}{|c|c|c|c|c|c|}
\hline Sava-N ( $\neg$ Kaj), e.g., Prekmurje & dện & $m e ̣ ̂ h$ & mêd & snệig & $s a ̂ d$ \\
\hline Sava-N Kajkavian & diên & $m i e \hat{h}$ & $m \hat{e} d$ & sniêg & sâd \\
\hline Sava-S, e.g., Standard Slovene & dan & mah & $m \hat{\mathrm{e}} \mathrm{d}$ & Snềg & sâd \\
\hline
\end{tabular}

\section{Accentuation}

In a number of respects Prekmurje accentuation is indicative of an older stage of accentual developments than central Slovene, on which the standard is based. Figure 9 is taken from sec. 118 of $\mathrm{VN}$ and shows the full preservation of mobility in the inherited Common Slavic c-paradigm, which has been leveled to columnar root stress in Ljubljana dialect and in unmarked standard speech (for details see Toporišič 2000: 290-291; Greenberg 2008: 28-29). Generally, mobility in this category is well preserved in everyday speech in Prekmurje Slovene, as confirmed by the author's field notes. This situation is consistent with the peripheral position of Prekmurje with respect to the center.

Figure 10. Paradigm of rôka 'hand' (VN §118)

\begin{tabular}{|c|c|c|c|}
\hline Case & Singular & Dual & Plural \\
\hline Nominative & rôk-a & rôki, rôk-êe & rok-é \\
\hline Accusative & rok-ô & rôki, rôk-êe & rok-é \\
\hline Genitive & rok-é, rôk-e & rôki, rôk-êe, rôk & rôk \\
\hline Dative & rôk-i, rok-êe & rok-áma & rok-ám \\
\hline Locative & pri rôk-i, rok-ê & pri rok-áma & pri rok-áj, rok-aj \\
\hline Instrumental & z rok-ôv & z rok-áma & z rok-ámi \\
\hline
\end{tabular}

In at least two respects the accentuation pattern diverges in ways that indicate early differences in the developments of the Prekmurje from the center. Because both of these issues have been discussed at length elsewhere, a summary here will suffice (see, for example, Greenberg 1993: 478-482; Greenberg 2000: 93, 105-109). The earlier one is the preservation of lengthened thematic $e$ in the present tense of c-paradigm verbs of the type *nese $\left(t z^{\prime}\right)>\mathrm{VN}$ neszé. Though this lengthening is the normal reflex of stress retracted from final jers, its occurrence in the c-paradigm verbs is lim- 
ited to three discontinuous areas (until others are discovered): Prekmurje, Carinthia (the far western periphery in Zilja), and Central Slovak (and, consequently, standard Slovak). Finally, the well-known archaism of the restriction in the realization of the circumflex advancement (Figure 12), which has been treated in several works, may be mentioned (see Greenberg 2000: 105-108 and literature cited there). This archaism demonstrates that weak jers in Proto-Prekmurje Slovene were still counted as syllables at the time the reevaluation of place of stress took place, underlining again the peripheral nature of Prekmurje with regard to innovations originating in the center of the Slovene territory.

Figure 11. Length in c-stressed e-presents

\begin{tabular}{|l|l|l|l|l|}
\hline PSI & Prekmurje & Carinthia (Zilja) & C. Slovak & Standard Slovene \\
\hline${ }^{*}$ nese $(t \grave{b})>$ & neszé $(\mathrm{VN})$ & nasẹ́ & nesie & nése \\
\hline${ }^{*}$ bere $(t \grave{b})>$ & beré $(\mathrm{VN})$ & barẹ́ & berie & bére \\
\hline
\end{tabular}

Figure 12. Restrictions on circumflex advancement

\begin{tabular}{|l|l|l|}
\hline PSI & Prekmurje & Standard Slovene \\
\hline${ }^{*}$ pobbralı $>$ & pôbrao $(\mathrm{VN})$ & pobrâl \\
\hline${ }^{*} l$ bgъko $>$ & lêko $(\mathrm{VN})$ & lahkộ \\
\hline
\end{tabular}

\section{A lexical marker}

We shall conclude this brief survey with a summary of the analysis of a lexical archaism found in Prekmurje and most of the remaining Pannonian Slovene dialect area, ${ }^{10}$ indicating not only its peripheral position with respect to central Slovene, but that regarding the earliest migrations to the Balkans and sub-Alpine regions, speakers of Proto-Prekmurje-Slovene (i.e., its founder population) had affinities with ProtoBulgarian speakers in a way that indicates a disjuncture with both the founder speech communities that were to give rise to the dialects corresponding to both Slovene and BCS. This indicates that the founder population of what was to become Prekmurje Slovene was at least in some ways unique within the sub-Alpine area and suggests that it acquired innovative features later from its neighbors that brought it into the Slovene and, to a lesser extent, the Kajkavian diasystems.

The Slavic standard languages attest a relatively small number of expressions for the notion 'speak'. In addition to OCS glagolati one finds today BCS govoriti, $\mathrm{Be} z a$ варыць, Вg говоря, Ru говорить, Sk hovorit', Sn govoriti; Cz mluvit, Po mówić, Uk мовити; Ма зборува; LS rjac, US réс̌е́c. However, the picture in Slavic dialects is much more complex. Among those lexemes for 'speak' that occur only in the dialects is PS *gzlčéti, a verb whose meaning was originally 'make sound/noise', as is evidenced by older attestations, e.g., OCS gzlkъ, - $a$ 'hluk, шум, Lärm, tumultus'; $\mathrm{OCz}$ hlučěti, $-u$, - $i s ̌ s$ 'hlučeti, křičeti, schallen, lärmen, schreien, rufen', hluk, -a 'hřmot, křik, prudkost, nepokoj, Lärm, Geschrei, Unruhe, Ungestüm'; ORu гълчати, гълчу 'кричать', гълчание 'шумъ, крикъ', гълка 'шумъ, мятежь'. The verb shifted to the

\footnotetext{
${ }^{10}$ Readers interested in the detailed exposition may consult Schallert and Greenberg
} 2007. 
meaning 'speak' in a subset of Slavic dialects, currently attested in three disparate regions of Slavic-central and northern Russian dialects and, in the South Slavic area, Bulgarian and the Pannonian Slovene dialect, a semantic shift that is paralleled in a number of cases both at the Indo-European and Slavic levels. The lexeme is lacking altogether in the BCS standard languages and is attested all but marginally in the dialects associated with them, this being due to secondary influence from the direction of Slovene as regards Kajkavian Croatian and from Bulgarian as regards Serbian.

The distribution observed for Eastern South Slavic is consistent with the proposition that *gzlčéti was brought to the southern Balkan peninsula from the Danube basin (i.e., primarily from the northeast, thus conceivably relating to the points in northern and central Russian dialects, adduced above) rather than from the northwest, a movement consistent with archaeological and linguistic observations on the migration patterns of the South Slavic settlement in recent years (see Andersen 1999 and literature cited there). This proposition is supported by the likelihood that the Slovene Pannonian dialect was settled from the southeast via the Danube and Sava basins by speakers of an early Slavic dialect or dialects in which *gzlčéti had also taken root. It also dovetails with the apparent total absence of * gzlčét in BCS (with the exceptions noted here for NE Torlak and above for points in Kajkavian and Cakavian), since the Morava and Vardar valleys would have most likely served as the primary channels for settlement of Macedonia, where the verb is also not found.

\section{Conclusion}

The preceding sketches of linguistic structural points and historical developments on which Prekmurje Slovene grammar diverges from both Slovene and BCS demonstrates the need for the consideration of at least the standardized form of this "forgotten" dialect among researchers examining the Slavic languages. For this reason it would be useful for the field of Slavic linguistics to obtain a published version of Pavel's 1942 grammar, Vend nyelvtan, which represents the only attempt to create a standardized version of the language in the twentieth century. As mentioned above, the present author is engaged in the project of preparing this grammar for publication.

Each point that has been sketched here represents a way in which Prekmurje grammar helps to illuminate an issue in Slavic linguistics. The analysis of the lexical item *gzlčetti sheds light on one the darkest periods of Slavic prehistory: the time of the settlement of the South Slavs in the Balkans and the sub-Alpine region. This is the kind of fragmentary evidence that can be mined from the lexical data of dialect studies; though it but adumbrates a general connection between Proto-Slavic dialect groups, it at least gives us a sense of the complexity of sociolinguistic relations at a stage long before nascent Slovene, BCS, Bulgarian, or Macedonian speech communities can be identified. Phonological and accentual developments illuminate later periods that demonstrate the gradual integration of disparate and heterogeneous speech communities. Some instances, such as the lengthening of the $e$-presents of the c-paradigm verbs demonstrate innovations carried through in central Slovak, Carinthian, and Prekmurje Slovene, most likely belong to that stage of development in which a 
Slavic speech community continued across the Pannonian Basin before the arrival of the Hungarians. Later, but still early developments show that early stages of Carinthian and Pannonian Slovene, as well as Kajkavian, formed a dialect continuum with the interplay of archaisms and innovations resulting in interlocking sets of outcomes in the vowel systems, depending on the relative chronology of the waves of innovation. In many respects, Prekmurje lies outside of or carries through later innovations originating in the central Slovene dialects, which is a logical consequence of its distance from the center.

In addition to issues of historical-comparative interest, Prekmurje grammar raises issues of typological import that call for a reassessment of the inventory of grammatical types found in the South Slavic languages. In the case of the encoding of semantic distinctions in complementizers $d a$ vs. $k a$, Prekmurje Slovene indicates that a simple dichotomy between Western (Slovene, BCS), lying outside of the Balkan Sprachbund, and Eastern (Macedonian, Bulgarian) South Slavic, lying in it, is too simplistic.

\begin{abstract}
Abbreviations
$\mathrm{ACC}=$ accusative $; \mathrm{AUX}=$ auxiliary verb; $\mathrm{Bg} .=$ Bulgarian; $\mathrm{COMP}=$ complementizer; $\mathrm{COND}=$ conditional; $\mathrm{DAT}=$ dative $;$ dial.$=$ dialect; $\mathrm{F}=$ feminine $; \mathrm{FF}=$ Freising Folia $=$ Bernik et al. 1993; $\mathrm{FUT}=$ future; $\mathrm{IMP}=$ imperative; $\mathrm{IMPF}=$ imperfective; $\mathrm{M}=$ masculine; $\mathrm{N}=$ neuter; OCS = Old Church Slavic (quoted from Blagova et al. 1994); $\mathrm{PF}=$ perfective; $\mathrm{PL}=$ plural; $\mathrm{Po} .=$ Polish; $\mathrm{SG}=$ singular; $\mathrm{REFL}=$ reflexive; $\mathrm{VN}=$ Vend nyelvtan $=$ Pável 1942
\end{abstract}

\title{
References
}

Ammann, Andreas and Johan van der Auwera. 2004. Complementizer-Headed Main Clauses for Volitional Moods in the Languages of South-Eastern Europe. Olga Mišeska Tomić, ed. Balkan Syntax and Semantics (Linguistik Aktuell/Linguistics Today, v. 67): 293-314. Amsterdam: John Benjamins.

Andersen, Henning. 1999. The Western South Slavic Contrast Sn. sah-ni-ti $\|$ sah-nu-ti. Slovenski jezik/Slovene Linguistic Studies: 47-62.

Blagova, È., et al. 1994. Staroslavjanskij slovar' (po rukopisjam X-XI vekov). Moscow: Russkij jazyk.

Bernik, France, et al., eds. 1993. Brižinski spomeniki. Znanstvenokritična izdaja. Ljubljana: SAZU.

Greenberg, Marc L. 1989. Ágost Pável's Prekmurje Slovene Grammar. Slavistična revija 37: 353-364.

- - 1993. Glasoslovni opis treh prekmurskih govorov in komentar k zgodovinskemu glasoslovju in oblikoglasju prekmurskega narečja. Slavistična revija 41/4: 465-487

- 2000. A Historical Phonology of the Slovene Language (= Historical Phonology of the Slavic Languages, 13). Heidelberg: C. Winter Universitätsverlag.

- - 2004. The Pannonian Slavic Dialect of the Common Slavic Proto-Language. $\mathrm{Ca}$ nadian Slavonic Papers XLVI/1-2: 213-220. 
- - 2005. Dialect Variation along the Mura. Croatica et Slavica Iadertina 1: 107124.

--2006. “The Slovene Sound System Through Time." Slavistična revija 54 (Posebna številka: Slovensko jezikoslovje danes/Slovenian Linguistics Today): 535-543.

- - 2008. A Short Reference Grammar of Slovene (= LINCOM Studies in Slavic Linguistics 30). Munich: Lincom.

Grickat, Irena. 1975. Studije iz istorije srpskohrvatskog jezika. Belgrade: Narodna biblioteka S. R. Srbije.

Kopečný, František et al. 1980. Etimologický slovník slovanských jazyků. Slova gramatická a zájmena, sv. 2. Spojky, částice, zájmena a zájmenna adverbia. Prague: ČSAV.

Janda, Richard D. and Brian D. Joseph. 2003. On Language, Change, and Language Change - Or, Of History, Linguistics and Historical Linguistics. Joseph, Brian D. and Richard D. Janda, eds. The Handbook of Historical Linguistics: 3-180. Oxford: Blackwell.

Jesenšek, Marko. 1998. Jezik prekmurskih abecednikov in učbenikov v 19. stoletju. Slovensko-madžarski jezikovni in književni stiki od Košiča do danes: 121-138. Budapest: Košičev sklad.

Lundberg, Grant H. 2007. Perceptual Dialectology and the Future of Slovene Dialects. Slovenski jezik/Slovene Linguistic Studies 6: 97-109.

Mukič, Francek. 2005. Porabsko-knjižnoslovensko-madžarski slovar. Szombathely: Zveza Slovencev na Madžarskem.

Novak, Vilko. 2007. Slovar stare knjižne prekmurščine. Ljubljana: ZRC SAZU.

Pavel, Avgust (Pável Ágost). 1917. Vend szöveggyüjtemény s az eddigi gyüjtések története. Nyelvtudomány 6/3: 161-187.

- - 1918. Vend szöveggyüjtemény s az eddigi gyüjtések története (folytatás és vége). Nyelvtudomány 6/4: 263-282.

- - 1942. Vend nyelvtan. Unpublished ms., Vashidegkut (Cankova) and Szombathely.

Priestly, Tom. 1996. Denial of Ethnic Identity: The Political Manipulation of Beliefs about Language in Slovene Minority Areas of Austria and Hungary. Slavic Review 55/2: 364-398.

Schallert, Joseph and Marc L. Greenberg. 2007. The Prehistory and Areal Distribution of Slavic *gъlčěti 'Speak'. Slovenski jezik/Slovene Linguistic Studies 6: 9-76.

Sihler, Andrew L. 1995. New Comparative Grammar of Greek and Latin. New York, Oxford: Oxford University Press.

Snoj, Marko. 1996. Kaj je kaj? Škrabčeva misel II. Zbornik s simpozija '96: 187-192. Nova gorica: Frančiškanski samostan Kostanjevica.

- - 2003. Slovenski etimološki slovar. Ljubljana: Modrijan.

Temlin, Franc. 1715 [1986]. Mali Katechismus dr. Martina Luthra [Facsimile edition]. Murska Sobota: Pomurska založba.

Toporišič, Jože. 2000. Slovenska slovnica. Maribor: Obzorja.

Vermeer, Willem. 1986. The Rise of the North Russian Dialect of Common Slavic. Dutch Studies in Russian Linguistics (= Studies in Slavic and General Linguistics 8): 503-515. Amsterdam: Rodopi.

Zdovc, Paul. 1972. Die Mundart des südöstlichen Jauntales in Kärnten. Lautlehre 
und Akzent der Mundart der "Poljanci" (= Schriften der Balkankommission Linguistische Abteilung XX). Vienna: ÖAW.

Prispelo septembra 2008, sprejeto oktobra 2008

Received September 2008, accepted October 2008

\section{Prekmurska slovnica kot vir slovanskega primerjalnega gradiva}

Prispevek zagovarja objavo Pavlove rokopisne prekmurske slovnice Vend nyelvtan, dokončane 1. 1942. Čeprav je prvotni namen slovnice, tj. uveljavitev pokrajinskega knjižnega jezika, zastarel, rokopis ponuja informacije o posebnem ustroju prekmurščine in je s tem tudi dragocen vir za tipološke, primerjalne in zgodovinske študije slovanskih jezikov.

Prekmurščina se je kot narečje razvijala z znatnimi posebnostmi in ima tudi kot knjižni jezik svojo lastno zgodovino, začenši z verskimi besedili v 18. stol. (morda tudi prej, vendar besedila niso ohranjena) vse do načrtovanega (a nikoli ne uporabljenega) knjižnega jezika v Pavlovem Vend nyelvtanu (rokopis 1942, Sombatelj in Cankova). Avtor referata je soavtor s komentarji opremljene znanstvene izdaje te slovnice, za katero pripravlja opombe o jezikovnih posebnostih prekmurščine in njihovi vrednosti za kontrastivno in primerjalno analizo slovanskih jezikov in narečij. Prekmurščina se na vseh ravneh razlikuje ne le od knjižne slovenščine in hrvaščine (oz. bosanščine in srbščine), temveč tudi od sosednje hrvaške kajkavščine.

Med posebnosti prekmurščine lahko prištejemo zgodnje glasoslovne razvoje, ki jo povezujejo s koroščino in hrvaško kajkavščino. Zanimiva leksikalna izoglosa je prisotnost odraza za leksem *gъlčéti kot primarnega izraza za 'govoriti', praslovanska narečna inovacija, ki povezuje prekmurščino z arhaičnim osrednjeruskim in bolgarskim narečjem, ne kaže pa povezanosti z osrednjo slovenščino ali bosanskimi, hrvaškimi ali srbskimi narečji. To nam daje vpogled v zgodnje selitvene tokove pri prvih južnoslovanskih naseljencih. Članek obravnava tudi razvrstitev podrednih veznikov $d a$ in $k a$, kjer $d a$ deluje kot označevalec (a) časovnih in (b) hipotetičnih pogojnih odvisnikov, medtem ko se $k a$ uporablja kot (c) označevalec realnih pogojnih odvisnikov. Ta razvrstitev se tipološko razlikuje tako od slovenščine kot od bosanščine/ hrvaščine/srbščine, izkazuje pa nekaj podobnosti z vzorci, ki jih najdemo v vzhodni južni slovanščini in balkanski jezikovni zvezi.

\section{Prekmurje Grammar as a Source of Slavic Comparative Material}

The paper makes the case for the publication of the 1942 Prekmurje Slovene grammar in manuscript, Avgust Pavel's Vend nyelvtan not for the purpose of reviving a competing literary language, but as a useful source of information for typological, comparative and historical studies of the Slavic languages.

The language of Prekmurje had both a divergent organic development as well 
as its own trajectory as a standard language, beginning with religious tracts in the eighteenth century (and possibly earlier, though texts have not survived) and culminating in the standardized version of the language planned but not implemented in Avgust Pavel's Vend nyelvtan (Prekmurje Slovene grammar, ms. 1942, Szombathely and Cankova). As part of the project of annotating the scholarly edition of the Vend nyelvtan, the author highlights some of the special features of Prekmurje Slovene, pointing out their value for the contrastive and comparative study of Slavic languages and dialects. At each level of analysis, Prekmurje Slovene differs from both Standard Slovene and Standard BCS, as well as the neighboring Croatian kajkavian dialect.

Among the indicators of the individuality of Prekmurje Slovene in the context of the Slovene Pannonian dialects Prekmurje Slovene has early phonological developments that link it with the Carinthian dialect of Slovene and the Croatian Kajkavian dialect. An interesting lexical isogloss is the presence of the reflex of *gzlčéti as the primary lexeme for 'speak', a Common Slavic dialectal innovation that links archaic dialect in central Russia and Bulgaria and indicating no connection with either central Slovene or any of the dialects associated with Bosnian/Croatian/Serbian. This suggests a glimpse of early migration patterns among the South Slavic founder populations. Also highlighted is the analysis of the distribution of subordinating conjunctions $d a$ vs. $k a$, where $d a$ functions as a marker of (a) temporality, (b) irrealis (hypothetical) propositions, and $k a$ as (c) realis (factual) propositions. This distribution diverges typologically from Slovene and BCS and demonstrates some similarity to the pattern found in eastern South Slavic and the Balkan Sprachbund. 